\title{
OPTIONS FOR REDUCTION OF MAIZE SILAGE IN Biogas Plant Drazenci
}

\author{
VINDIS, P.; STAJNKO, D. \& LAKOTA, M.
}

Abstract: The aim of the research is to compare the yield of biogas and methane in the biogas plant Drazenci in the current production of biogas compared with biogas produced using a lower proportion of maize silage on the basis of theoretical calculations. Calculations for three different scenarios for the recovery of biogas and methane have been made and then the scenarios compared. For the current production the biogas plant uses poultry manure, corn silage and waste fats in the ratio 70:25:5. The total yield of $148 \mathrm{~m}^{3}$ of biogas/t fresh weight and the yield of 90.16 $\mathrm{m}^{3}$ of methane with one ton input substrate mixture were calculated. It was found that the highest yield of biogas and methane was obtained in scenario 1 which is currently applied in the biogas plant Drazenci. When comparing the calculated values for yield, it has been found that there are options for reducing corn silage in the input substrate, which may be replaced by waste fats that feature high energy potential.

Key words: biogas plant, poultry manure, biogas production, corn silage, methane
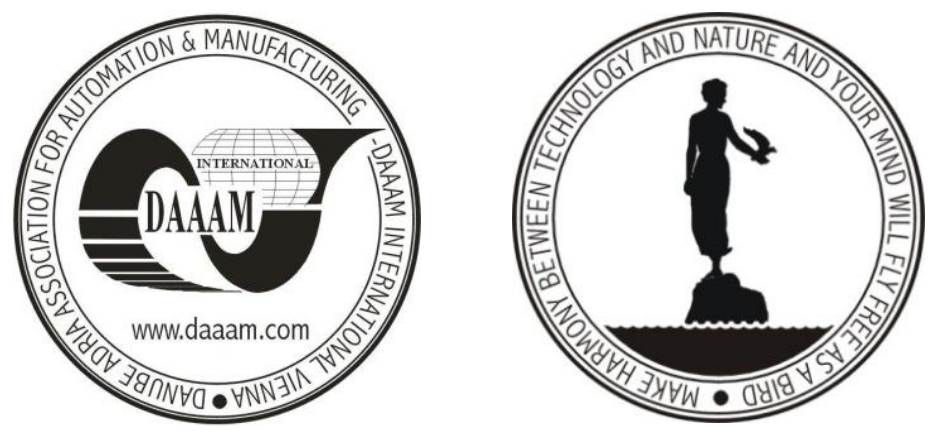

Authors' data: Assist. Prof. Dr. Vindis, P[eter]; Assoc. Prof. Stajnko, D[enis]; Assoc. Prof. Lakota, M[iran], University of Maribor, Faculty of Agriculture and Life Sciences, Pivola 10, SI-2311, Hoce, Slovenia, peter.vindis@um.si, miran.lakota@um.si,denis.stajnko@um.si.

This Publication has to be referred as: Vindis, P[eter]; Stajnko, D[enis] \& Lakota, M[iran] (2014). Options for Reduction of Maize Silage in Biogas Plant Drazenci, Chapter 09 in DAAAM International Scientific Book 2014, pp.121-130, B. Katalinic (Ed.), Published by DAAAM International, ISBN 978-3-901509-98-8, ISSN 17269687, Vienna, Austria

DOI: 10.2507/daaam.scibook.2014.09 
Vindis, P.; Stajnko, D. \& Lakota, M.: Options for Reduction of Maize Silage in Bio...

\section{Introduction}

Agricultural residues, including manure and energy crops, represent an important source of biomass that can serve as a substrate in anaerobic digestion, resulting in the production o $\mathrm{f}$ renewable energy. Within EU, these types of biomasses could amount to 1545 million tonnes per year, if 760 tonnes of energy crops were produced each year (Vindis et al., 2008). Sustainable biogas production from energy crops must not be based on maximum yields from single crops, but on maximum methane yield from sustainable and environmentally friendly crop rotations (Amon et al., 2007).

Traditionally it is primarily manure that is digested in farm-scale digesters. However, in Germany, where substantial subsidies are provided for electricity produced from biogas which is produced on a farm scale, energy crops are used as co-substrates in more than $90 \%$ of the digesters to increase the gas yield (Weiland, 2003).

Biogas is a mixture of gases resulting from the anaerobic fermentation (without presence of oxygen) in the biogas plant, under certain conditions (temperature, pressure). The collapse of biomass and animal by-products is carried out by means of decomposition of microorganisms or bacteria (Crolla \& Kinsley, 2010). Biogas is most commonly used in cogeneration units allowing production of electricity and heat. Biogas as a renewable source of energy can be produced mainly from all organic materials containing a satisfactory ratio between carbon and nitrogen (Monnet, 2003).

In the process of anaerobic fermentation undesirable products are caused dangerous for the environment due to the presence of greenhouse gases. For biogas production the animal by-products, energy crops, municipal waste, waste processed in food industry and waste from households are used. When cleaning the biogas, which runs through various processes, it is particularly important to remove most of the unwanted impurities and raise the proportion of methane. Biogas cleaned up to the level where it can be replaced by natural gas, is known as bio methane (Jejčič, 2010).

The purpose of the study is to determine what the yield of methane and biogas in the biogas production in biogas plant Drazenci (Fig. 1) is compared with biogas produced from a lower proportion of maize silage in raw material input. We will compare the amount of input and output materials, the most important being the yield of biogas and methane. We are interested in the comparison of biogas in the plant Drazenci (current production) with biogas produced with a lower percentage of corn silage.

The aim of the research is to show different possibilities of maintaining the same level of production of biogas (methane) with a lower proportion of maize silage as input for biogas production and to obtain data of yield of biogas and methane production for different options of production. 


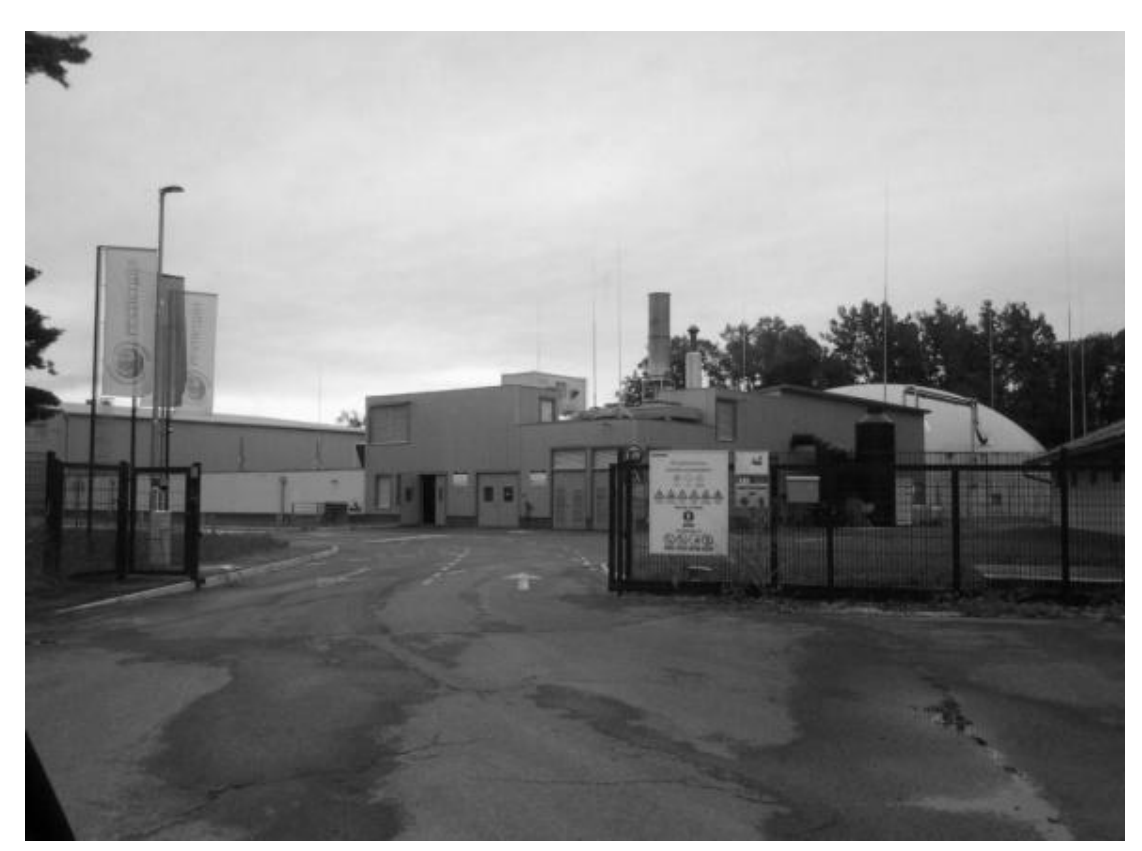

Fig. 1. Biogas plant Drazenci

\subsection{Biogas composition}

Composition of biogas depends primarily on the biogas production method and the conditions in which it originates. In the process of anaerobic fermentation it is possible to use all kinds of biomass containing fats, proteins, carbohydrates, cellulose and hemicellulose (Braun, 2003) as main ingredients. The composition of the biogas is mainly affected by the efficiency of anaerobic fermentation process, the residence time and the substrate itself (Braun, 2007).

In general, the biogas composition is shown in Table 1.

\begin{tabular}{|l|c|c|}
\hline Methane (\%) & $\mathrm{CH}_{4}$ & $50-75$ \\
\hline Hydrogen sulphide (\%) & $\mathrm{H}_{2} \mathrm{~S}$ & $0-1$ \\
\hline Hydrogen (\%) & $\mathrm{H}_{2}$ & $0-1$ \\
\hline Nitrogen (\%) & $\mathrm{N}_{2}$ & $0-3$ \\
\hline Oxygen (\%) & $\mathrm{O}_{2}$ & $0-1$ \\
\hline Water steam (\%) & $\mathrm{H}_{2} \mathrm{O}$ & $2-7$ \\
\hline Carbon dioxide (\%) & $\mathrm{CO}_{2}$ & $25-45$ \\
\hline Ammonia (\%) & $\mathrm{NH}_{3}$ & $0-0,5$ \\
\hline
\end{tabular}

Tab. 1. Biogas composition

\section{Methods}

\subsection{Presentation of possible scenarios}

Herebelow, 3 different possible scenarios will be presented assumed and calculated on theoretic basis. Substrates used in experiment are poultry manure with bedding, corn silage and floating fat. Table 2 shows the composition of materials and biogas yield for input materials in our experiment.

All ratios are listed in the following order: poultry manure, corn silage and waste fats, where maize silage was not used (the ratio of poultry manure and waste fats). 
Vindis, P.; Stajnko, D. \& Lakota, M.: Options for Reduction of Maize Silage in Bio...

\begin{tabular}{|c|c|c|c|c|c|}
\hline SUBSTRATE & $\begin{array}{c}\text { Dry matter } \\
\text { (\% of fresh } \\
\text { mass) }\end{array}$ & $\begin{array}{c}\text { Dry organic } \\
\text { matter (\% of } \\
\text { fresh mass) }\end{array}$ & $\begin{array}{c}\mathbf{m}^{\mathbf{3}} \mathbf{C H}_{\mathbf{4}} / \mathbf{t} \\
\mathbf{d r y} \text { organic } \\
\text { matter }\end{array}$ & $\begin{array}{c}\mathbf{C H}_{\mathbf{4}} \\
\text { (vol \%) }\end{array}$ & $\begin{array}{c}\mathbf{m}^{\mathbf{3}} \text { biogas/t } \\
\text { fresh mass }\end{array}$ \\
\hline $\begin{array}{c}\text { Poultry manure } \\
\text { with bedding }\end{array}$ & 32 & 24 & 350 & 65 & 130 \\
\hline Corn silage & 33 & 31,7 & 330 & 52,5 & 200 \\
\hline Floating fat & 15 & 13,5 & 680 & 68 & 140 \\
\hline
\end{tabular}

Tab. 2. Substrates used in the experiment, their composition and yield of biogas

\subsubsection{Presentation of scenario 1}

In the first scenario the current production of biogas takes place in the plant Drazenci . They currently produce biogas from $70 \%$ of poultry manure, $25 \%$ corn silage and 5\% fat. According to the available substrates, in two different possible scenarios a $10 \%$ increase of the share of poultry manure would be considered, because it abounds, while corn silage represents a cost and is originally intended for animal nutrition on their farms. Measurements of biogas and methane are measured automatically and are controlled via the on-line system as shown in Figure 2.

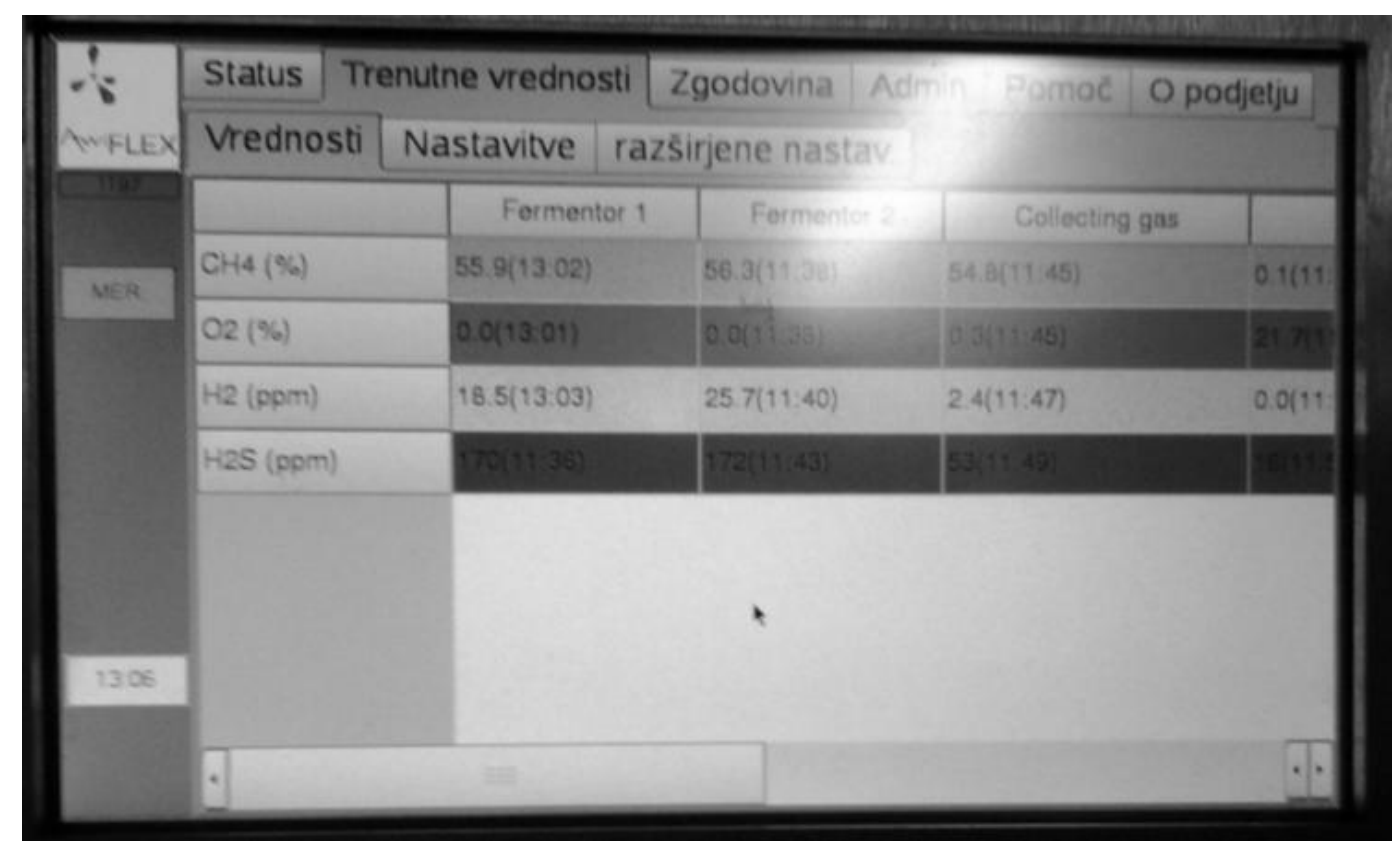

Fig. 2. Display of current values of individual gases in the substrate mixture

On the screen it is possible to see different values of individual gases for fermenter 1 and fermenter 2. It shows the measured values for methane, oxygen and hydrogen in percentages and sulphide $\left(\mathrm{H}_{2} \mathrm{~S}\right)$ in ppm. Figure 2 shows the current value of the biogas composition according to the first scenario, where the proportion of 
methane in the fermenter 1 is $55.9 \%$ and in the fermenter $256.3 \%$. In the total biogas the methane proportion is $54.8 \%$. Oxygen contents are under $1 \%$, which indicates the anaerobic fermentation. The biggest problem is the sulphide $\left(\mathrm{H}_{2} \mathrm{~S}\right)$, since it is necessary to strive for its lowest possible value.

Figure 3 shows two horizontal fermenters, which are a specialty of biogas plant Drazenci and allow measurements of gas.

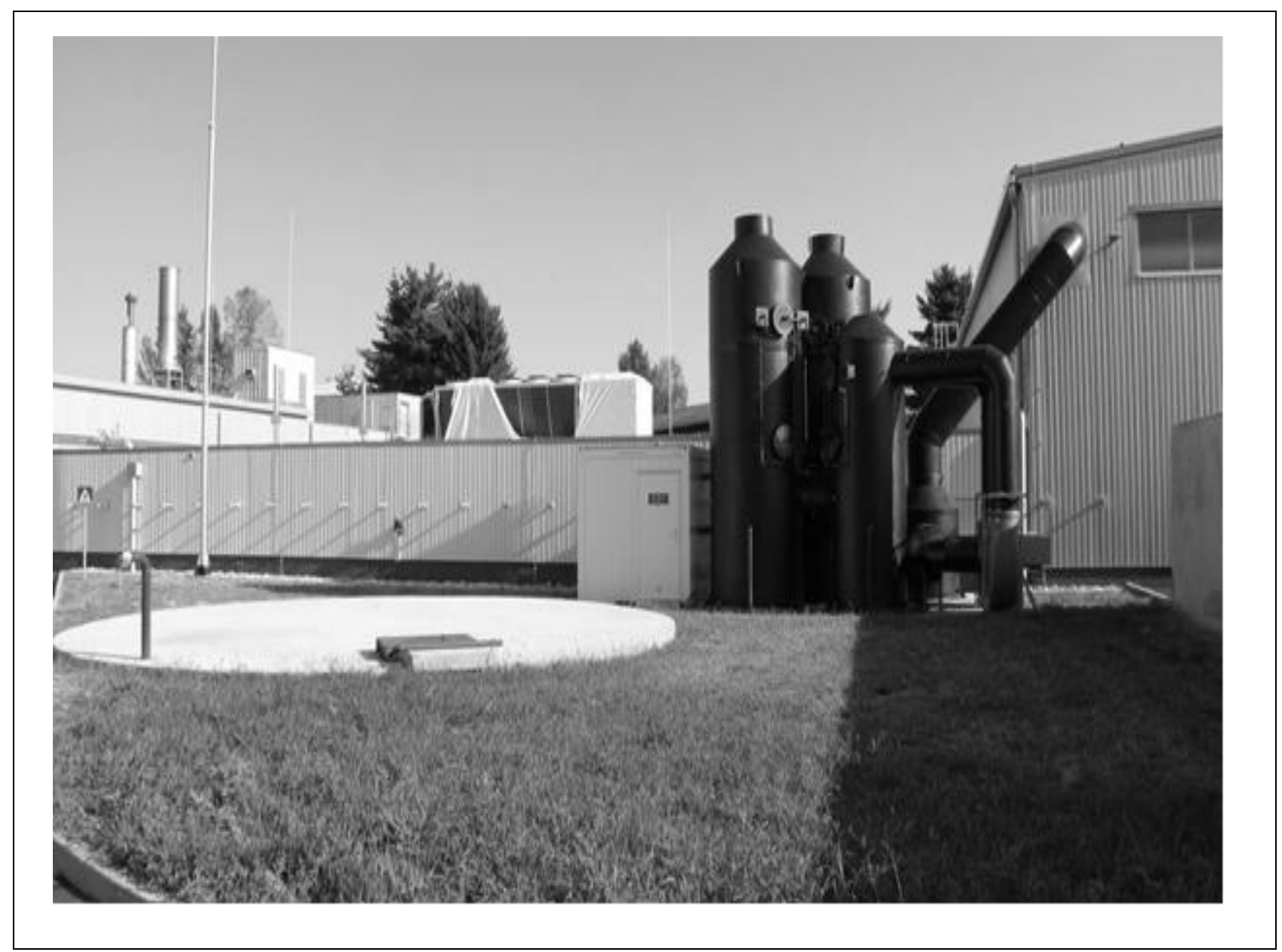

Fig. 3. Two horizontal fermenters of the biogas plant Drazenci

\subsubsection{Presentation of scenario 2}

In the second possible scenario, the content of maize silage in the input substrate was reduced for $10 \%$ and waste fat increased for $10 \%$. The main input substrate poultry manure was retained in the same amount as in scenario 1 . Substrates in scenario 2 appear in the ratio of $70 \%$ poultry manure, $15 \%$ corn silage and $15 \%$ of waste fats.

\subsubsection{Presentation of scenario 3}

In the third possible scenario, the content of the main substrate poultry manure was increased for $10 \%$, ie from 70 to $80 \%$. Taking into account the initial value, the content of corn silage in the input substrate was reduced for $15 \%$ from 25 to $10 \%$. The content of waste fats was increased from the original $5 \%$ to $10 \%$. 
Vindis, P.; Stajnko, D. \& Lakota, M.: Options for Reduction of Maize Silage in Bio...

\section{Results}

In the results the amount of produced biogas and methane will be compared scenario by scenario. The results for each scenario were first shown in the tables. For illustration for each scenario graphic display showing the yield of biogas and methane was made. For scenario 1 the dry matter content and the dry organic matter were calculated in relation to the amount of input substrate mixture.

\subsection{Results of scenario 1}

Table 3 shows the calculation of dry matter content and the content of organic dry matter in relation to the quantity of the substrate and in relation to dry matter and dry organic matter in the substrate listed in Table 2. Table 3 shows that poultry manure constitutes $70 \%$ of the total input substrate, i.e. 0.7 ton of poultry manure per ton of input substrate. Dry matter represents 0,224 tons while dry organic matter 0,168 tons. Corn silage represents a quarter of the total input substrate. In the 0.25 ton of corn silage the dry matter content is 82.5 kilograms, the proportion of dry organic matter is $79.25 \mathrm{~kg}$. The least proportion is waste fat which is only $5 \%$. In the $50 \mathrm{~kg}$ of waste fat the percentage of the dry matter is $7.5 \mathrm{~kg}$ while the proportion of organic dry matter is $6.75 \mathrm{~kg}$.

\begin{tabular}{|c|c|c|c|}
\hline Substrate & Quantity $(\mathrm{t})$ & Dry matter $(\mathrm{t})$ & Dry organic matter $(\mathrm{t})$ \\
\hline Poultry manure & 0,7 & 0,224 & 0,168 \\
\hline Corn silage & 0,25 & 0,0825 & 0,07925 \\
\hline Used fats & 0,05 & 0,0075 & 0,00675 \\
\hline TOTAL & 1 & 0,314 & 0,254 \\
\hline
\end{tabular}

Tab. 3. The amount of substrate (t), dry matter content ( $\mathrm{t}$ ) and the content of dry organic matter $(\mathrm{t})$ per ton of substrate mixture according to the scenario 1

Table 4 shows the calculations for the biogas and methane yield for scenario 1 with one ton of the total input substrate. The poultry manure, which appears also in the maximum percentage in the input substrate, produces the maximum yield of biogas and methane, namely $91 \mathrm{~m}^{3}$ of biogas and $59,15 \mathrm{~m}^{3}$ of methane. With $25 \%$ share of maize silage in the input substrate the calculated yield is $50 \mathrm{~m}^{3}$ of biogas and $26,25 \mathrm{~m}^{3}$ of methane. Used fats which appear in the input substrate also in the lowest percentage give the lowest yield of biogas. The yield is $7 \mathrm{~m}^{3}$ of biogas and $4,76 \mathrm{~m}^{3}$ of methane. Total biogas yield for scenario 1 is $148 \mathrm{~m}^{3} / \mathrm{t}$ fresh mass while total methane yield is $90.16 \mathrm{~m}^{3}$ with one ton of input substrate mixture. The last column of Table 4 shows methane yield in $\mathrm{m}^{3} / \mathrm{t}$ dry organic matter and can be compared with results from literature (Al seadi et al., 2010). 


\begin{tabular}{|c|c|c|c|c|c|c|}
\hline Substrate & $\begin{array}{c}\text { Quantity of } \\
\text { the } \\
\text { substrate }(\mathrm{t})\end{array}$ & $\begin{array}{c}\text { Biogas yield } \\
\left(\mathrm{m}^{3} / \mathrm{t} \text { of fresh }\right. \\
\text { mass })\end{array}$ & $\begin{array}{c}\text { Biogas } \\
\text { yield }\left(\mathrm{m}^{3} /\right. \\
\text { fresh mass })\end{array}$ & $\begin{array}{c}\text { Methane } \\
\text { content } \\
(\%)\end{array}$ & $\begin{array}{c}\text { Methane } \\
\text { yield } \\
\left(\mathrm{m}^{3}\right)\end{array}$ & $\begin{array}{c}\text { Methane yield } \\
\left(\mathrm{m}^{3} / \mathrm{t} \text { dry }\right. \\
\text { organic matter })\end{array}$ \\
\hline $\begin{array}{c}\text { Poultry } \\
\text { manure }\end{array}$ & 0,7 & 130 & 91 & 65 & 59,15 & 58,8 \\
\hline $\begin{array}{c}\text { Corn } \\
\text { silage }\end{array}$ & 0,25 & 200 & 50 & 52,5 & 26,25 & 26,15 \\
\hline Used fats & 0,05 & 140 & 7 & 68 & 4,76 & 4,6 \\
\hline TOTAL & 1 & & $\mathbf{1 4 8}$ & & $\mathbf{9 0 , 1 6}$ & $\mathbf{8 9 , 5 5}$ \\
\hline
\end{tabular}

Tab. 4. Biogas and methane yield $\left(\mathrm{m}^{3}\right)$ for scenario 1

Figure 4 shows that the maximum yield of biogas and methane is produced by poultry manure which appears in the input substrate in maximum percentage. Less yield of biogas and methane is from maize silage, while the smallest yield of biogas is from waste fats which represent only $5 \%$ of the total input substrate.

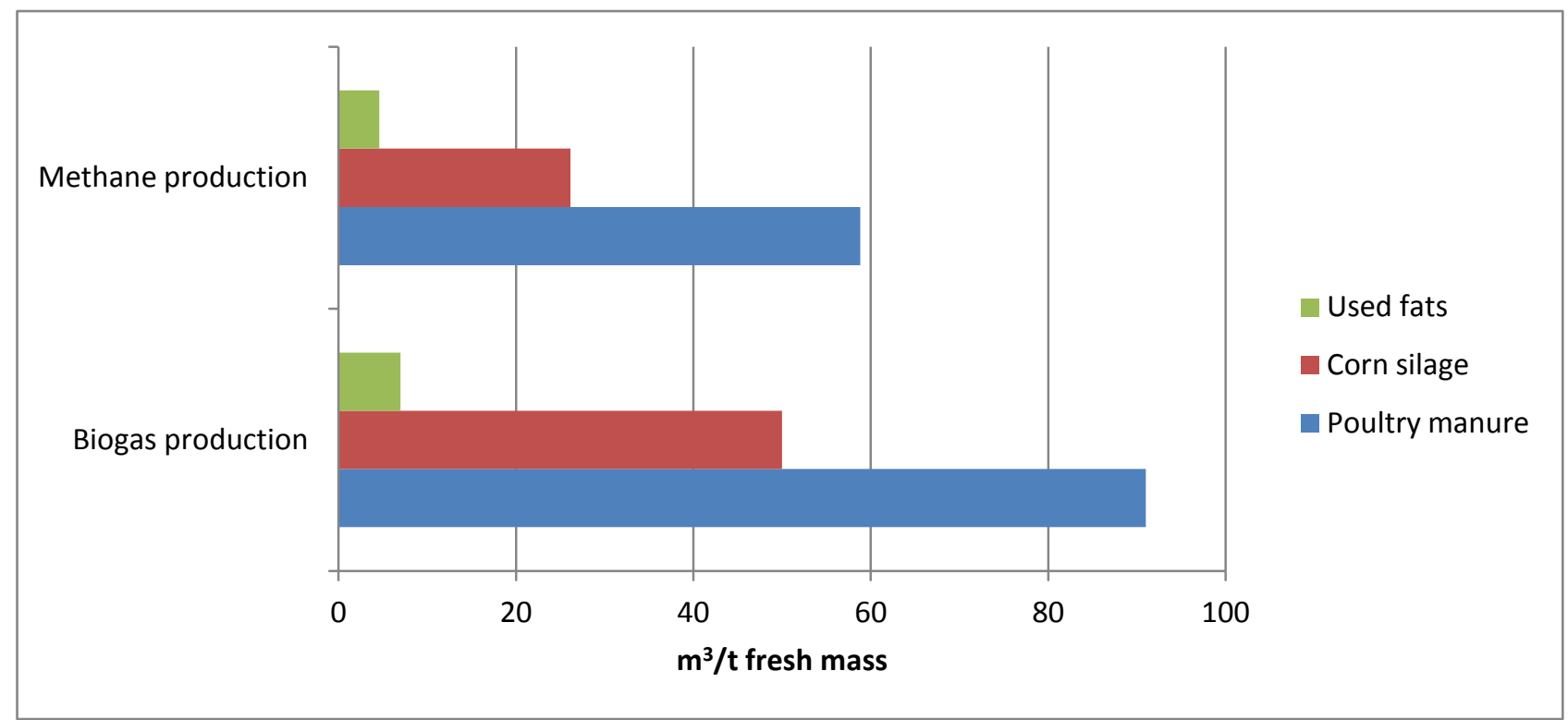

Fig. 4. Biogas and methane yield $\left(\mathrm{m}^{3} / \mathrm{t}\right.$ fresh mass) for scenario 1

\subsection{Results of scenario 2}

Table 5 shows the calculations for the biogas and methane yield for scenario 2 with one ton of the total input substrate. The maximum yield of biogas and methane is produced by poultry manure, which appears also in the maximum percentage in the input substrate, namely $91 \mathrm{~m}^{3}$ of biogas and $59,15 \mathrm{~m}^{3}$ of methane. With $15 \%$ share of maize silage in the input substrate a yield of $30 \mathrm{~m}^{3}$ of biogas and $15,75 \mathrm{~m}^{3}$ of methane is obtained; the lowest yield of biogas is obtained from used fats. Biogas yield from used fats is $21 \mathrm{~m}^{3}$ and methane yield $14,28 \mathrm{~m}^{3}$. Total biogas yield for scenario 2 is 142 $\mathrm{m}^{3} / \mathrm{t}$ fresh mass while total methane yield is $89.18 \mathrm{~m}^{3}$ per ton of input substrate mixture. 
Vindis, P.; Stajnko, D. \& Lakota, M.: Options for Reduction of Maize Silage in Bio...

\begin{tabular}{|c|c|c|c|c|c|c|}
\hline Substrate & $\begin{array}{c}\text { Quantity of } \\
\text { the } \\
\text { substrate }(\mathrm{t})\end{array}$ & $\begin{array}{c}\text { Biogas } \\
\text { yield } \\
\left(\mathrm{m}^{3} / \mathrm{t} \text { of }\right. \\
\text { fresh mass })\end{array}$ & $\begin{array}{c}\text { Biogas yield } \\
\left(\mathrm{m}^{3} / \text { fresh }\right. \\
\text { mass })\end{array}$ & $\begin{array}{c}\text { Methane } \\
\text { content }(\%)\end{array}$ & $\begin{array}{c}\text { Methane } \\
\text { yield }\left(\mathrm{m}^{3}\right)\end{array}$ & $\begin{array}{c}\text { Methane } \\
\text { yield } \\
\left(\mathrm{m}^{3} / \mathrm{t} \text { dry }\right. \\
\text { organic } \\
\text { matter })\end{array}$ \\
\hline $\begin{array}{c}\text { Poultry } \\
\text { manure }\end{array}$ & 0,7 & 130 & 91 & 65 & 59,15 & 58,8 \\
\hline Corn silage & 0,15 & 200 & 30 & 52,5 & 15,75 & 15,7 \\
\hline Used fats & 0,15 & 140 & 21 & 68 & 14,28 & 13,77 \\
\hline TOTAL & 1 & & $\mathbf{1 4 2}$ & & $\mathbf{8 9 , 1 8}$ & $\mathbf{8 8 , 2 7}$ \\
\hline
\end{tabular}

Tab. 5. Biogas and methane yield $\left(\mathrm{m}^{3}\right)$ for scenario 2

Figure 5 shows that the maximum yield of biogas and methane is produced by poultry manure, which appears in the input substrate in maximum percentage. Less yield of biogas and methane is from maize silage, while the smallest yield of biogas is from used fats.

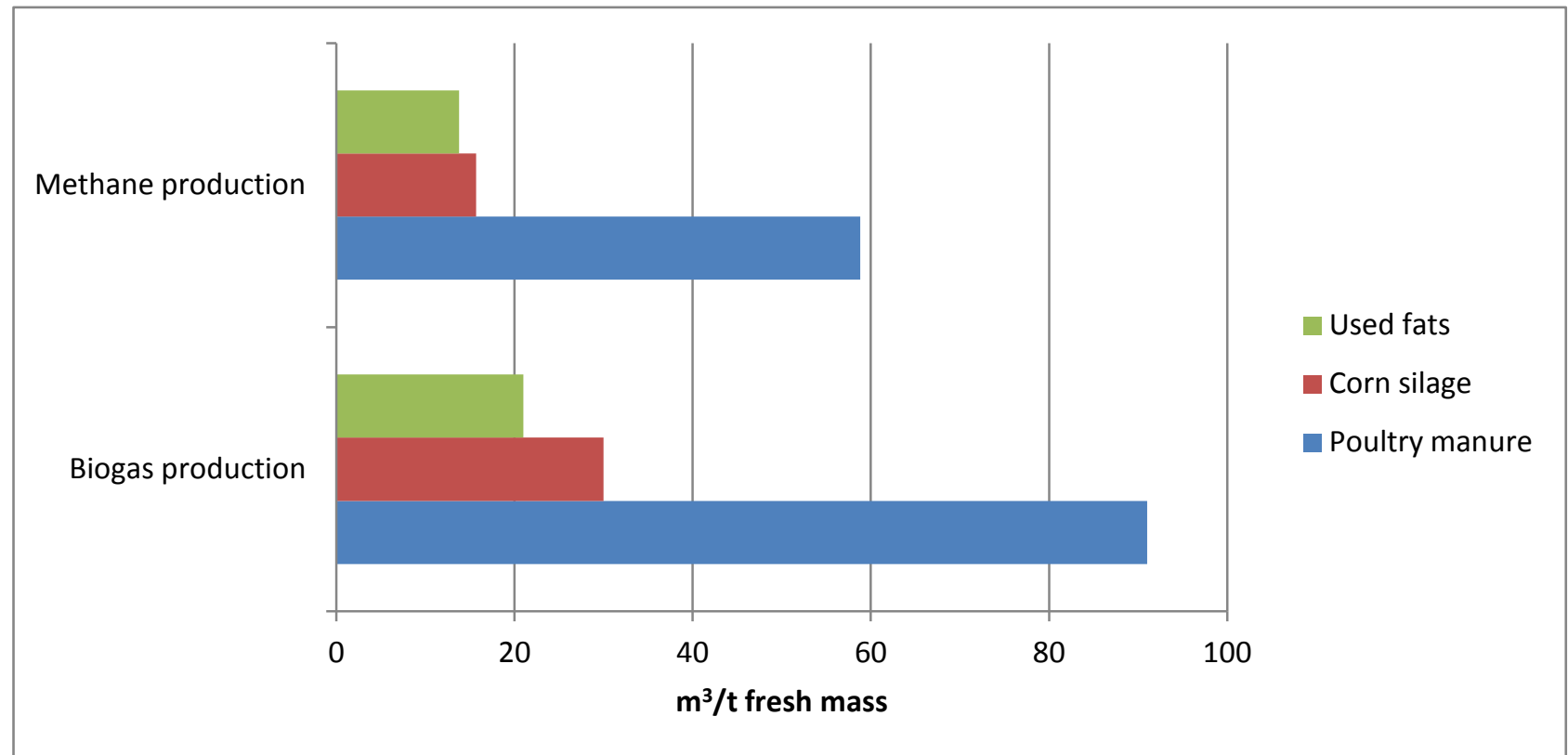

Fig. 5. Biogas and methane yield $\left(\mathrm{m}^{3} / \mathrm{t}\right.$ fresh mass) for scenario 2

\subsection{Results of scenario 3}

Table 6 shows the calculations for the biogas and methane yield for scenario 3 with one ton of the total input substrate. The maximum yield of biogas and methane is produced by poultry manure which appears also in the maximum percentage in the input substrate, namely $104 \mathrm{~m}^{3}$ of biogas and $67,6 \mathrm{~m}^{3}$ of methane. $10 \%$ share of maize silage in the input substrate gives a yield of $20 \mathrm{~m}^{3}$ of biogas and $10,5 \mathrm{~m}^{3}$ of methane.

The lowest yield of biogas is obtained from used fats, namely $14 \mathrm{~m}^{3}$ of biogas and $9,52 \mathrm{~m}^{3}$ of methane. Total biogas yield for scenario 3 is $138 \mathrm{~m}^{3} / \mathrm{t}$ fresh mass while total methane yield is $87.62 \mathrm{~m}^{3}$ at one ton of input substrate mixture. 


\begin{tabular}{|c|c|c|c|c|c|c|}
\hline Substrate & $\begin{array}{c}\text { Quantity of } \\
\text { the substrate } \\
(\mathrm{t})\end{array}$ & $\begin{array}{c}\text { Biogas } \\
\text { yield } \\
\left(\mathrm{m}^{3} / \mathrm{t} \text { of }\right. \\
\text { fresh mass })\end{array}$ & $\begin{array}{c}\text { Biogas } \\
\text { yield }\left(\mathrm{m}^{3} /\right. \\
\text { fresh mass })\end{array}$ & $\begin{array}{c}\text { Methane } \\
\text { content } \\
(\%)\end{array}$ & $\begin{array}{c}\text { Methane } \\
\text { yield }\left(\mathrm{m}^{3}\right)\end{array}$ & $\begin{array}{c}\text { Methane } \\
\text { yield }\left(\mathrm{m}^{3} / \mathrm{t}\right. \\
\text { dry organic } \\
\text { matter })\end{array}$ \\
\hline $\begin{array}{c}\text { Poultry } \\
\text { manure }\end{array}$ & 0,8 & 130 & 104 & 65 & 67,6 & 67,2 \\
\hline $\begin{array}{c}\text { Corn } \\
\text { silage }\end{array}$ & 0,10 & 200 & 20 & 52,5 & 10,5 & 10,46 \\
\hline $\begin{array}{c}\text { Used } \\
\text { fats }\end{array}$ & 0,10 & 140 & 14 & 68 & 9,52 & 9,18 \\
\hline TOTAL & 1 & & $\mathbf{1 3 8}$ & & $\mathbf{8 7 , 6 2}$ & $\mathbf{8 6 , 8 4}$ \\
\hline
\end{tabular}

Tab. 6. Biogas and methane yield $\left(\mathrm{m}^{3}\right)$ for scenario 3

Figure 6 shows that the maximum yield of biogas and methane is produced by poultry manure which appears in the input substrate in maximum percentage. Less yield of biogas and methane is from maize silage, while the smallest yield of biogas is from used fats.

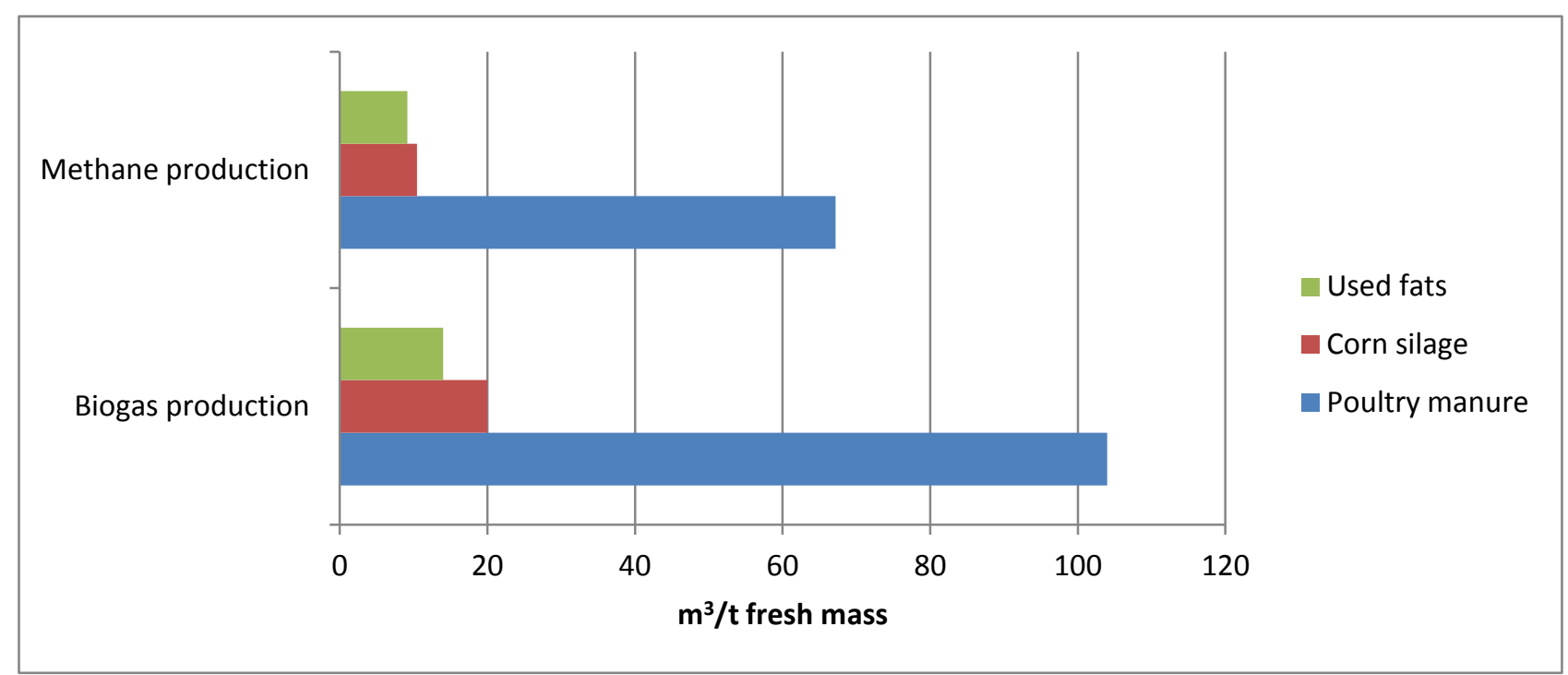

Fig. 6. Biogas and methane yield $\left(\mathrm{m}^{3} / \mathrm{t}\right.$ fresh mass) for scenario 3

\section{Conclusion}

In this study, the potential for reducing the amount of maize silage in the input substrate in the production of biogas in the biogas plant Drazenci has been compared and calculated. Three different scenarios for the production of biogas with reduced content of maize silage in the input substrate have been compared. Statements are theoretical in nature and are based on calculations. In analyzing the data, it has been found that there are opportunities to reduce maize silage in the input substrate. According to the results it can be confirmed that biogas plant Drazenci can maintain the same level of biogas production while reducing input substrate maize silage. Input substrate maize silage can be replaced by used fats. It can be concluded that the use 
Vindis, P.; Stajnko, D. \& Lakota, M.: Options for Reduction of Maize Silage in Bio...

of maize silage has a major impact on the production of biogas and that used fats significantly affect the yield of biogas and increase the methane content.

The maximum possible yield of biogas and methane was calculated for scenario 1 with the largest percentage of maize silage in the input substrate. Maize silage as energy plant is on the top of the biogas yield. Maize silage has a $200 \mathrm{~m}^{3}$ biogas yield per ton of fresh mass, compared with poultry manure that reaches the biogas yield of $130 \mathrm{~m}^{3}$ per tonne of fresh mass. The use of poultry manure for biogas plant Drazenci represents a minimal cost, because they have enough of this substrate. The most favourable option for the biogas plant Drazenci is replacing the whole of maize silage by used fats which also give a very high yield of biogas and methane. This scenario would also be the best for the biogas plant Drazenci, as far as they have available enough used fats, but unfortunately they do not.

Future research will focus on increasing the yield of biogas from waste materials (fats) and reduce the use of materials that are primarily used for food production (maize, cereals, ,...).

\section{References}

Al Seadi, T.; Rutz, D.; Prassl, H.; Korttner, M.; Finsterwalder, T.; Volk, S.; Janssen, R.; Grmek, M.; Vertin, K.; Blaznik, I.; Jereb, J. \& Domjan, S. (2010). Handbook on biogas, Energy Restructuring Agency, ISBN 978-961-92737-2-2, Ljubljana

Amon, T.; Amon, B.; Kryvoruchko, V.; Zollitsch, W.; Mayer K. \& Gruber. L. (2007). Biogas production from maize and dairy cattle manure - Influence of biomass composition on the methane yield. Agriculture, Ecosystems and Environment, Vol. 118, (173-182)

Braun, R. \& Wellinger, A. (2003). Potential of Co-digestion IEA Bioenergy Report 37. Energy from biogas and Landfill Gas. Austria

Braun, R. (2007). Anaerobic digestion: a multi-faceted process for energy, environmental management and rural development. V: Improvement of crop plants for industrial enduses. Springer, ISBN-10 1-4020-5485-8 (HB) Ronalli P. Berlin Crolla, A. \& Kinsley, C. (2010). Biochemical Methane Potential Tests Using Biomass and Food Industry Wastes as Co-substrates in Dairy Manure Anaerobic Digestion, Final report to OMAFRA

Jejčič, V. \& Poje T. (2010). Publication biogas in agriculture, information for biogas production in Slovenia. Ljubljana: Agricultural Institute of Slovenia Monnet (2003). An introduction to Digestion of Organic wastes. Final report : 7-15. Vindis, P.; Mursec, B.; Stajnko, D.; Brus, M. \& Janzekovic, M. (2008). Measuring biogas production with fermenters. Daaam international scientific book, chapter 78 , pp. $943-952$

Weiland, P. (2003). Production and energetic use of biogas from energy crops and wastes in Germany. Applied Biochemistry and Biotechnology, Vol. 109, pp. 263-274 